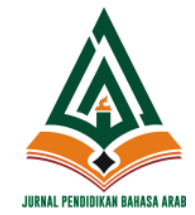

\author{
Alibbaa': Jurnal Pendidikan Bahasa Arab \\ Vol. 3 No. 1, January 2022 \\ P-ISSN: 2721-1606 | E-ISSN: 2716-4985 \\ doi: https://doi.org/10.19105/ajpba.v3i1.5172
}

\title{
Representasi Makna Denotasi dan Konotasi dalam Lirik Lagu Kun Fayakun (Analisis Semiotika Roland Barthes)
}

\author{
Trimo Wati, Dina Safira Ikmaliani, Mustolehudin \\ State Islamic University of Salatiga, Indonesia \\ State Islamic University of Salatiga, Indonesia \\ Religious Reseacrh and Development Center of Semarang, Indonesia \\ E-mail: zidnielzahwa@gmail.com
}

\begin{abstract}
This study aims to describe the meaning implied in the Arabic song "Kun Fayakun" lyrics through translation and study process analysis. As for this research, the author used the qualitative-descriptive method by making observations through existing data, looking for patterns between relationships with various concepts that have not been previously determined, analyzing, then providing understanding and explanations. The data were collected by observation and documentation technique and analyzed by Roland Barthes's semiotic theory. The outcome that was gained from this research is as follows: 12 the denotative and 12 connotative meaning which have an important role in helping the reader to understand the song lyrics of literary meaning and its implicit meaning.
\end{abstract}

Keywords: Semiotic, denotative, connotative, lyrics of song Kun Fayakun 


\section{Pendahuluan}

Pengaplikasian bahasa dapat diwujudkan dalam ide-ide atau gagasan-gagasan yang dikembangkan oleh manusia. Salah satunya adalah melalui seni dalam lagu. Menurut Hedi Sasrawan, seni adalah kemampuan membuat sesuatu dalam hubungannya dengan upaya mencapai suatu tujuan yang telah ditentukan oleh gagasan tertentu. Sedangkan musik adalah suara yang disusun sedemikian rupa sehingga mengandung irama, lagu, dan keharmonisan. Jadi bisa disimpulkan bahwa seni musik adalah sarana ekspresi seorang seniman yang menggunakan suara yang disusun sedemikian rupa, baik dengan menggunakan alat musik maupun suara vokal. ${ }^{1}$

Lirik lagu sebagai salah satu unsur pembangun dalam lagu atau musik dapat dikategorikan sebagai puisi dalam karya sastra. ${ }^{2}$ Sebagaimana dijelaskan oleh lembaga Depdiknas, lirik adalah karya sastra (puisi) yang berisi curahan perasaan pribadi. ${ }^{3}$ Dengan demikian lirik adalah bagian dari lagu di mana menggunakan bahasa untuk menyusunnya dan termasuk dalam karya sastra (puisi) yang dinyanyikan.

Lirik lagu menggambarkan sesuatu yang kemudian diperkaya akan perasaan, kekuatan imaji, serta kesan keindahan. Dalam membuat lirik lagu terkait dengan bahasa, dan bahasa akan terkait dengan sastra. Kata-kata (lirik lagu) yang dibuat oleh pencipta lagu tidak semua dapat dimengerti oleh khalayak, karena itulah memerlukan suatu penelitian tentang isi lirik lagu tersebut. Penentuan bahasa yang digunakan juga tergantung pada individual yang menciptakan lirik lagu, karena belum ada ketentuan bahasa dalam membuat sebuah lirik lagu, tetapi lirik yang dibuat dapat dipertanggung jawabkan isinya. Sedangkan tiap lirik yang dibuat oleh pencipta lagu pasti memiliki makna tersendiri yang ingin disampaikan kepada pendengarnya. ${ }^{4}$

1 Rif'ati Fauzan, "Kandungan Lirik Lagu Insya Allah Karya Maher Zain dalam Perspektif Al-Qu'an" Skripsi (2016). http://repository.iiq.ac.id/handle/123456789/672

2 Rendi Patria, Abdurahman Abdurahman, Bakhtaruddin Nasution, "Interpretasi Makna Lirik Lagu-Lagu Grup Musik ERK dalam Album ERK: Kajian Semiotika", Jurnal Bahasa dan Sastra, Vol. 1 No. 2, 2013: 69-82. http://ejournal.unp.ac.id/index.php/ibs/article/view/1481

${ }^{3}$ Ibid.

${ }^{4}$ Syarif Fitri, “Analisa Semiotik Makna Motivasi Lirik Lagu 'Cerita Tentang Gunung Dan Laut' Karya Payung Teduh,” Jurnal Komunikasi, Vol. 8 No. 3, 2017: 256-261. https://ejournal.bsi.ac.id/ejurnal/index.php/jkom/article/view/3071 
Di era modern seperti ini, musik sudah menjadi sebuah kebutuhan bagi manusia. Bagi pencipta musik, musik menjadi suatu luapan emosi jiwa, di mana perasaan yang ada di pencipta musik tersampaikan. Bagi penikmat musik, dengan mendengar musik yang sesuai dengan suasana hati maka harapannya agar bisa merasa lebih relaks dan lebih baik. ${ }^{5}$ Terkait dengan hal tersebut, maka lagu yang mengandung lirik-lirik religi dan pembangun semangat sangatlah perlu didengarkan.

Salah satu penyanyi yang mengembangkan nilai-nilai religi dalam lirik lagu-lagunya adalah Othman Ali Ibrahim. Dia adalah salah satu pebisnis dan musisi yang sering menyanyikan lagu-lagu berbahasa Arab. Salah satu lagu yang dinyanyikan olehnya adalah lagu Kun Fayakun. Di mana lagu tersebut dinyanyikan dengan mengambil nada dari lagu Memories milik Maroon 5 dan menyanyikannya dengan genre akapela.

Lagu Kun Fayakun diciptakan oleh seorang penyair dari Oman, yaitu Muhammad Bin Duhai. Selain penyair, dia adalah seorang komposer dan penulis konten kreatif. Dia mulai menulis puisi sejak tahun 2011 dan mulai menulis lagu sejak tahun 2018. Dia banyak memenangkan hadiah dalam kompetisi puisi nasional dan menjadi peserta paling menonjol dalam festival puisi Oman. Motivasi dia dalam berkarya bukan untuk memperkenalkan diri kepada orang-orang, melainkan untuk menyampaikan pesan karya seninya untuk menjangkau semua orang. ${ }^{6}$

Di lain sisi, banyak di kalangan masyarakat yang menganggap bahwa lagu-lagu berbahasa Arab adalah salawat. Padahal jika ditelusuri, sama halnya pada negara-negara lain yang memiliki musisimusisi dengan lagu yang memiliki maksud tersendiri yang ingin disampaikan kepada penikmat lagu. Sedangkan salawat sendiri menurut KBBI merupakan doa kepada Allah untuk Nabi Muhammad SAW

${ }^{5}$ Niswati Khoiriyah dan Syahrul Syah Sinaga, "Pemanfaatan Pemutaran Musik Terhadap Psikologis Pasien Pada Klinik Ellena Skin Care Di Kota Surakarta," Jurnal Seni Musik, Vol. 6 No. 2, 2017: 81-90. https://journal.unnes.ac.id/sju/index.php/jsm/article/view/20313

${ }^{6}$ Muhammad bin Duhai, penyair, Wawancara, Instagram, 7 September 2021. 
beserta keluarga dan sahabatnya ${ }^{7}$. Sehingga adakalanya lagu-lagu berbahasa Arab hanya dapat dinikmati tanpa tahu makna di dalamnya.

Berdasarkan uraian di atas, hal itulah yang melatarbelakangi peneliti untuk meneliti makna yang terdapat pada lirik lagu tersebut. Dalam menganalisis makna dalam lirik lagu tersebut, peneliti menggunakan metode semiotika Roland Barthes yang menyempurnakan semiologi Saussure yang berhenti pada penanda dan tataran denotasi. Sedangkan Barthes sampai kepada tataran konotasi. Semiotik pada dasarnya hendak mempelajari bagaimana manusiaan (humanity) memaknai hal-hal (things). Memaknai (to sinify) dalam hal ini tidak dapat dicampuradukkan dengan mengkomunikasikan (to communicate). Memaknai berarti objek-objek tidak hanya membawa informasi, dalam hal mana juga menkonstitusi system terstruktur dari tanda. ${ }^{8}$

Roland Barthes menganggap bahwa denotasi sebagai konotasi yang paling kuat dan paling akhir. Makna denotasi dianggap sebagai makna yang terlihat jelas dan dapat langsung diuraikan pada saat kita melihat tanda tersebut tanpa harus berfikir panjang. Sedangkan makna konotasi adalah makna yang tidak sebenarnya, tidak terlihat jelas dan tidak dapat diuraikan secara spontan ketika melihat tanda tersebut. ${ }^{9}$

Berkenaan dengan penelitian ini, peneliti menemukan beberapa penelitian tentang studi analisis lirik lagu yang relevan dan bersinggungan dengan artikel ini. Studi yang dilakukan M. Imran membahas lirik lagu Kun Anta yang mempunyai makna dalam dari aspek semiotik sehingga dapat diambil hikmah serta pelajaran dari lirik lagu tersebut. Pada penelitian dikemukakan bahwa beberapa kata maupun kalimat pada lirik lagu Arab Kun Anta yang dipopulerkan oleh Humood Alkhuder memiliki makna-makna semiotik, yang artinya kata

\footnotetext{
7 Badan Pengembangan dan Pembinaan Bahasa, "Kamus Besar Bahasa Indonesia Daring." https://kbbi.kemdikbud.go.id/

${ }^{8}$ Saiful Qadar Basri, “Tari Remo (Ngremong): Sebuah Analisis Teori Semiotika Roland Barthes Tentang Makna Denotasi Dan Konotasi Dalam Tari Remo

(Ngremong)," Jurnal Seni Tari Drama, Vol. 2 No. 1, 2019: 55-69.

https://journal.unesa.ac.id/index.php/geter/article/view/4800

${ }^{9}$ Devi Arie Shandy, "Representasi Makna Pesan Dakwah Dalam Lirik Lagu Tomat (Tobat Maksiat) Pada Album Ingat Shalawat Karya Wali Band," Jurnal Online Mahasiswa (JOM) Bidang Ilmu Sosial dan Ilmu Politik, Vol. 1 No. 2, 2014: 1-15. https://jom.unri.ac.id/index.php/JOMFSIP/article/view/3010
} 
atau kalimat itu mengandung pesan moral yang dapat diambil dari lagu tersebut. ${ }^{10}$

Studi lain yang juga bersinggungan dengan penelitian ini, dilakukan oleh Devi Arie Shandy. Artikel yang ditulis Devi Arie Shandy membahas tentang makna denotasi dan konotasi pesan dakwah dalam lirik lagu TOMAT, selain itu juga terdapat analisis mitos pesan dakwah dalam lirik lagu TOMAT (Tobat Maksiat). Pada penelitian ini dikemukakan bahwa dalam lirik lagu TOMAT (Tobat Maksiat) terdapat makna denotasi dan konotasi yang terdapat pada lima bagian lirik. Selain itu juga mengandung mitos dan representasi makna pesan dakwah dalam lirik lagu tersebut. ${ }^{11}$

Kajian lain juga dilakukan oleh Syarif Fitri yang membahas tentang makna pesan Motivasi yang terdapat dalam lirik lagu berjudul "Cerita Tentang Gunung dan Laut". Di mana penulis menemukan ada makna dibalik lirik lagu tersebut tentang motivasi kehidupan. Pada penelitian ini dikemukakan bahwa makna pesan Motivasi yang terdapat dalam lirik lagu berjudul "Cerita Tentang Gunung dan Laut" adalah tentang motivasi kehidupan. ${ }^{12}$

Ketiga Penelitian di atas memiliki beberapa kesamaan dengan penelitian penulis, baik dalam kajian teori yang digunakan ataupun studi kasus yang menggunakan lagu arab dan non-arab. Penelitian pertama ((M. Imron) merupakan penelitian menggunakan teori semiotika Charles Sanders Pierce dengan studi kasus lagu bahasa arab Kun Anta. Penelitian yang kedua (Devi Arie Shandy) merupakan penelitian yang menganalisis lirik lagu yang kemudian diambil makna secara khususnya. Perbedaan terletak pada objek yang diteliti dan penelitian ini tidak menganalisis mengenai mitos. Kemudian penelitian ketiga (Syarif Fitri) yang merupakan analisis semiotik terhadap sebuah objek. Hanya saja berbeda dalam teori yang digunakan. Untuk penelitian tersebut menggunakan teori semiotik Saussure, sedangkan

10 M Imron, "Semiotika Dalam Lirik Lagu Arab Kun Anta Yang Dipopulerkan Oleh Humood Alkhuder," Skripsi (2018). https://repository.uinjkt.ac.id/dspace/handle/123456789/40585

${ }^{11}$ Shandy, "Representasi Makna Pesan Dakwah Dalam Lirik Lagu Tomat (Tobat Maksiat) Pada Album Ingat Shalawat Karya Wali Band."

12 Fitri, "Analisa Semiotik Makna Motivasi Lirik Lagu 'Cerita Tentang Gunung Dan Laut’ Karya Payung Teduh.” Jurnal Komunikasi, Vol. 8 No. 3, 2017. https://ejournal.bsi.ac.id/ejurnal/index.php/jkom/article/view/3071 
untuk penelitian ini menggunakan teori analisis Roland Barthes, serta objek yang dianalisis berbeda. Jadi penelitian ini berbeda dengan penelitian sebelumnya dari segi obyek penelitian, yaitu lagu Kun Fayakun.

Selanjutnya, lagu sebagai salah satu media hiburan dan perantara untuk menyampaikan pesan yang terkadung di dalamnya. Sehingga lagu dikemas dengan lirik yang mengandung makna tersendiri. Sehingga banyak orang yang merasa tertarik untuk menjadikan lagu sebagai objek yang harus diteliti. Penelitian ini berangkat dari mayoritas masyarakat yang mengganggap bahwa lagu berbahasa arab adalah salawat. Selain itu minimnya kajian mengenai lagu berbahasa Arab, sehingga peneliti berusaha untuk mengungkap dan menjelaskan makna yang terkadung dalam lagu berbahasa Arab, khususnya lagu Kun Fayakun.

Fokus permasalahan dalam penelitian ini adalah bagaimana lirik-lirik lagu Kun Fayakun mencerminkan makna-makna kebaikan dengan analisis semiotik Roland Barthes. Adapun tujuan penelitian ini adalah untuk menganalisis makna yang terkandung dalam lirik lagu Kun Fayakun.

\section{Metode Penelitian}

Metode yang digunakan dalam penelitian ini adalah penelitian kualitatif dengan metode deskriptif. Penelitian ini lebih menekankan pada analisis makna denotasi dan konotasi dalam lirik lagu Kun Fayakun. Data primer dalam penelitian ini adalah lirik lagu Kun Fayakun. Sedangkan untuk data sekunder atau data tambahan berupa buku-buku, jurnal, skripsi, web, serta sumber lainnya yang berhubungan dengan objek penelitian.

Kemudian teknik pengumpulan data dalam penelitian ini adalah observasi dan dokumentasi. Observasi atau pengamatan atau lebih tepatnya mendengarkan serta membaca lirik lagu "Kun Fayakun" oleh Othman Ali Ibrahim, menerjemahkan dan menganalisisnya sehingga mampu menemukan pesan dalam lagu tersebut. Sedangkan untuk teknik dokumentasi dengan cara mengumpulkan data-data berupa lirik lagu "Kun Fayakun", jurnal, skripsi, dan sumber-sumber lainnya. Kemudian mempelajari dokumen-dokumen tersebut guna memperoleh data atau informasi yang berhubungan dengan masalah yang diteliti. 
Teknik analisis data yang diterapkan dalam penelitian ini ialah teknik analisis semiotika Roland Barthes yang menekankan perhatiannya terhadap lambang-lambang yang mengalami retak teks. Maksud retak teks di sini adalah bagian (kata, kalimat, istilah, paragraf) dari teks yang ingin dicari tahu artinya atau dipertanyakan lebih lanjut maknanya. Peneliti akan membagi keseluruhan lirik lagu menjadi per dua baris yang kemudian akan dianalisis menggunakan teori semiotika Roland Barthes. Dengan melakukan pembagian yaitu pemisahan per dua larik lagu, maka akan mempermudah peneliti dalam melakukan interpretasi atau pemaknaan pada setiap tanda pada lirik lagu "Kun Fayakun" oleh Othman Ali Ibrahim, karena makna dari setiap dua baris lirik lagu tersebut berkaitan satu sama lain.

\section{Hasil dan Pembahasan}

Semiotika sebagai ilmu yang tidak dapat dilepaskan dari pentingnya makna. Barthes mencoba mengungkap makna-makna yang terdapat dalam teks dan $S / Z$ sebagai representasi atas analisis tekstualnya dalam memperdalam semiotika. Makna terbagi menjadi dua bagian, yaitu makna konotasi dan denotasi. ${ }^{13}$ Penelitian ini menggunakan teori dari Saussure dan Roland Barthes. Barthes mengemukakan teori semiotik yang bertumpu pada teori dikotomis Saussure. Saussure membagi tanda menjadi dua bagian yaitu signifier (penanda) dan signified (petanda).

Dalam teori Barthes, menurut Dadan Rusmana, ia mengembangkan semiotika menjadi dua tingkatan tanda, yaitu tingkat denotasi dan konotasi. ${ }^{14}$

\footnotetext{
${ }_{13}$ Jafar Lantowa, dkk., Semiotik Teori, Metode, Dan Penerapannya Dalam Penelitian Sastra (Yogyakarta: Deepublish, 2012), hlm. 126.

${ }^{14}$ Rina Septiana, "MAKNA DENOTASI, KONOTASI DAN MITOS DALAM FILM KEIN WHO AM I KEIN SYSTEM IST SICHER (SUATU ANALISIS

SEMIOTIK)," JURNAL ELEKTRONIK FAKULTAS SASTRA UNIVERSITAS SAM

RATULANGI, Vol. 1 No. 2, 2019: 1-4.

https://ejournal.unsrat.ac.id/index.php/jefs/article/view/24151
} 


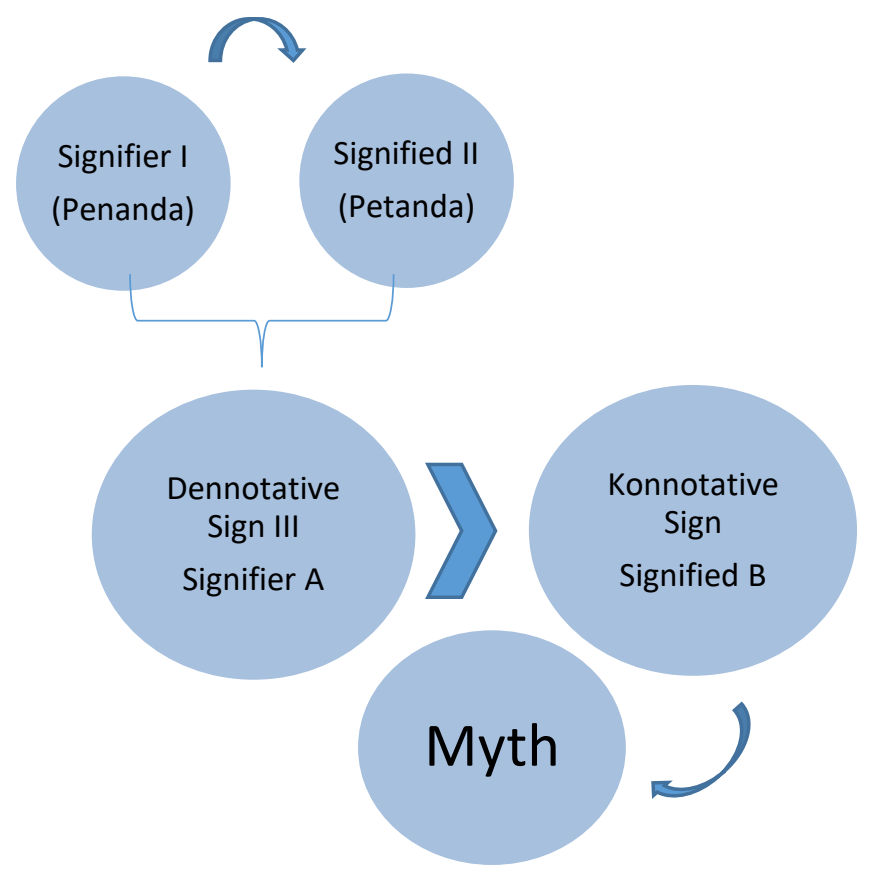

Menurut Paul Cobley \& Litza Jansz sebagaimana dikutip dari David Ardhy Aritonang \& Yohannes Don Bosco Doho (2019) dapat disimpulkan dari peta Barthes di atas, bahwasanya tanda denotatif terdiri atas penanda dan petanda. Namun, pada waktu yang sama, tanda denotatif juga merupakan penanda konotatif. Kemudian penanda konotatif tersebut akan memunculkan petanda konotatif yang menjadi dasar munculnya tanda konotatif. Bagi Barthes, semiotika bertujuan untuk memahami sistem tanda, apapun substansi dan limitnya, sehingga seluruh fenomena sosial yang ada dapat ditafsirkan sebagai 'tanda' alias layak dianggap sebagai sebuah lingkaran linguistik. ${ }^{15}$

Tahap denotasi ini baru menelaah tanda dari sudut pandang bahasa dalam hal ini yaitu makna harfiah. Dari pemahaman bahasa ini, kita dapat masuk ke tahap kedua, yakni menelaah tanda secara konotasi. Pada tahap ini konotasi menggambarkan interaksi yang berlangsung ketika tanda bertemu dengan perasaan atau emosi penggunanya dan nilai-nilai kulturalnya. Konotasi bekerja dalam

15 David Ardhy Aritonang and Yohannes Don Bosco Doho, "Analisis Semiotika Roland Barthes Terhadap Lirik Lagu Band Noah 'Puisi Adinda'," Ilmu Komunikasi dan Bisnis, Vol. 4 No. 2, 2019: 77-103. http://www.journal.starki.id/index.php/JIK/article/view/217 
tingkat subjektif sehingga kehadirannya tidak disadari. Dalam teori semiotik Barthes, terdapat juga mitos sebagai sistem pemaknaan tingkat kedua. ${ }^{16}$

Menurut Barthes, denotasi merupakan tanda yang penandanya mempunyai tingkat kesepakatan yang tinggi yang menghasilkan makna sesungguhnya. Bagi Barthes, denotasi merupakan sistem signifikasi tingkat pertama sedangkan konotasi merupakan sistem signifikasi tingkat kedua. Barthes (Rusmana, 2014) menyatakan bahwa sastra merupakan contoh paling jelas bagi sistem pemaknaan tataran kedua yang dibangun di atas bahasa sebagai sistem yang pertama. Tahap denotasi ini baru menelaah tanda dari sudut pandang bahasa dalam hal ini yaitu makna harfiah.

Dari pemahaman bahasa ini, kita dapat masuk ke tahap kedua, yakni menelaah tanda secara konotasi. Pada tahap ini konotasi menggambarkan interaksi yang berlangsung ketika tanda bertemu dengan perasaan atau emosi penggunanya dan nilai-nilai kulturalnya. Konotasi bekerja dalam tingkat subjektif sehingga kehadirannya tidak disadari. Dalam teori semiotik Barthes, terdapat juga mitos sebagai sistem pemaknaan tingkat kedua. ${ }^{17}$

Denotasi memiliki makna yang bersifat secara langsung, yaitu makna khusus yang terdapat pada tanda, dan pada intinya dapat disebut sebagai gambaran petanda. Makna ini didasarkan atas penunjukan yang lugas pada sesuatu di luar bahasa atau yang didasarkan atas konvensi tertentu; memiliki sifat objektif. ${ }^{18}$

Proses signifikasi denotasi biasanya mengacu pada penggunaan bahasa dengan arti yang sesuai dengan apa yang terucap. Misalnya ketika seseorang mengucapkan kata "anjing" maka yang dimaksudkan dari pengucapan kata "anjing" tersebut adalah konsep tentang keanjingan, seperti berkaki empat, mamalia, mengigit dan suka menggonggong. Dalam semiotika Barthes, denotasi merupakan sistem

${ }^{16}$ Septiana, "Makna Denotasi, Konotasi dan Mitos dalam Film Kein."

17 John, Asril, and Agung Eko Budi Waspada, "Analisis Semiotika Logo Rumah Makan Patinku," Proporsi, Vol. 3 No. 1, 2017): 33-43. http://ejournal.potensi-utama.ac.id/ojs/index.php/PROPORSI/article/view/551

${ }^{18}$ Nova Dwiyanti, "Analisis Semiotik Citra Wanita Muslimah Dalam Film 'Assalamualaikum Beijing”” Tesis (2016): 1-111. http://repository.uinsu.ac.id/1351/ 
signifikasi tingkat pertama, yang kemudian dilanjutkan oleh sistem signifikasi konotasi yang berada di tingkat kedua. ${ }^{19}$

Istilah konotasi digunakan Barthes untuk menunjukkan sistem signifikasi tahap kedua. Kata konotasi itu sendiri berasal dari bahasa Latin connotare, "menjadi tanda" dan mengarah pada makna-makna kultural yang terpisah/berbeda dengan kata atau bentuk-bentuk lain dari komunikasi. Makna konotatif ialah gabungan dari makna denotatif dengan segala gambaran, ingatan, dan perasaan yang ditimbulkan ketika indera kita bersinggungan dengan petanda.

Konotasi diartikan sebagai aspek makna sebuah atau sekelompok kata yang didasarkan atas perasaan atau pikiran yang timbul atau ditimbulkan pada pembicara dan pendengar selain itu juga memiliki makna subjektif dan berhubungan dengan emosional. ${ }^{20}$

\section{Analisis Makna Denotasi pada Lirik Lagu Kun Fayakun}

Sebagaimana dijelaskan di atas bahwasanya makna denotasi merupakan makna harfiah atau makna asli, maka dalam penelitian ini, peneliti mengklasifikasikan lirik lagu yang berbahasa arab sebagai penanda denotatif yang mana setelah itu diterjemahkan dan dicari makna harfiahnya sebagai petanda denotatif.

1. Makna denotasi pada dua larik pertama pada lagu Kun Fayakun

حِيْنَمَا حَلَّ الْبََاْء

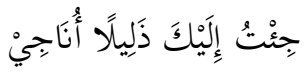

\begin{tabular}{ccl}
\hline Lirik & Terjemah & \multicolumn{1}{c}{ Makna KBBI } \\
\hline Ketika & $\begin{array}{l}\text { Kata penghubung untuk menandai waktu } \\
\text { yang bersamaan; tatkala; pada waktu (yang } \\
\text { bersamaan) }\end{array}$ \\
\hline Lَ & Menimpa & Jatuh menindih (mengenai) sesuatu \\
\hline
\end{tabular}

${ }^{19}$ Aritonang and Doho, "Analisis Semiotika Roland Barthes Terhadap Lirik Lagu Band Noah ' Puisi Adinda'."

20 Dwiyanti, "Analisis Semiotik Citra Wanita Muslimah Dalam Film 'Assalamualaikum Beijing'." 
ALIBBAA': Jurnal Pendidikan Bahasa Arab, 3 (1), 2022

\begin{tabular}{|c|c|c|}
\hline 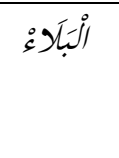 & Ujian & $\begin{array}{l}\text { Sesuatu yang dipakai untuk menguji mutu } \\
\text { sesuatu (kepandaian, kemampuan, hasil } \\
\text { belajar, dan sebagainya); cobaan }\end{array}$ \\
\hline جاء & Hadir & Ada; (ada) datang \\
\hline$\stackrel{8}{ت}$ & Saya & $\begin{array}{l}\text { Orang yang berbicara atau menulis (dalam } \\
\text { ragam resmii atau biasa); aku }\end{array}$ \\
\hline إلي & Ke, kepada & Kata depan untuk menandai arah atau tujuan \\
\hline كَ & Kamu & $\begin{array}{l}\text { Yang diajak bicara; yang disapa (dalam } \\
\text { ragam akrab atau kasar) }\end{array}$ \\
\hline ذَلِيلا & Merendah & Tidak menyombong (angkuh) \\
\hline 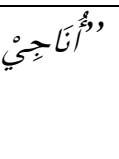 & Berlindung & $\begin{array}{l}\text { Minta pertolongan kepada Tuhan Yang } \\
\text { Mahakuasa supaya selamat atau terhindar } \\
\text { dari godaan, bencana, dosa }\end{array}$ \\
\hline
\end{tabular}

Dapat dilihat dari arti per kata di atas, kesimpulannya makna denotasi pada dua baris pertama adalah ketika musibah menimpa, aku akan datang merendah memohon kepada (Tuhan) nya.

2. Makna denotasi pada dua larik kedua pada lagu Kun Fayakun

$$
\begin{aligned}
& \text { مَنْ لِيْ غَيْرَكَ رَبِّيْ }
\end{aligned}
$$

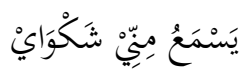

\section{Lirik Terjemah Makna KBBI}

\begin{tabular}{|c|c|c|}
\hline مَنْ & Siapa & $\begin{array}{l}\text { kata tanya untuk menanyakan nomina } \\
\text { insan }\end{array}$ \\
\hline 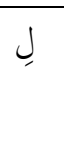 & Bagi & $\begin{array}{l}\text { Kata depan untuk menyatakaan perihal; } \\
\text { akan (hal); tentang (hal); menurut } \\
\text { (pendapat) }\end{array}$ \\
\hline 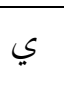 & $\begin{array}{l}\text { Saya (kata } \\
\text { ganti) }\end{array}$ & $\begin{array}{l}\text { Orang yang berbicara atau menulis (dalam } \\
\text { ragam resmi atau biasa) }\end{array}$ \\
\hline 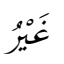 & Selain & Kecuali; lain daripada \\
\hline
\end{tabular}




\begin{tabular}{|c|c|c|}
\hline 5 & $\begin{array}{l}\text { Kamu (kata } \\
\text { ganti) }\end{array}$ & $\begin{array}{l}\text { Yang diajak bicara; yang disapa (dalam } \\
\text { ragam akrab atau kasar) }\end{array}$ \\
\hline رَبُّ & Tuhan & $\begin{array}{l}\text { sesuatu yang diyakini, dipuja, dan } \\
\text { disembah oleh manusia sebagai yang } \\
\text { Mahakuasa, Mahaperkasa, dan sebagainya }\end{array}$ \\
\hline ي & $\begin{array}{l}\text { Saya (kata } \\
\text { ganti) }\end{array}$ & $\begin{array}{l}\text { Orang yang berbicara atau menulis (dalam } \\
\text { ragam resmi atau biasa) }\end{array}$ \\
\hline يَسْمَعُع & Mendengarkan & $\begin{array}{l}\text { Memperhatikan; mengindahkan; menurut } \\
\text { (nasihat, bujukan, dan sebagainya) }\end{array}$ \\
\hline 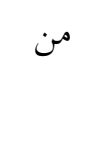 & Dari & $\begin{array}{l}\text { Kata depan yang menyatakan tempat } \\
\text { permulaan (dalam ruang, waktu, deretan, } \\
\text { dan sebagainya) }\end{array}$ \\
\hline ي & $\begin{array}{l}\text { Saya (kata } \\
\text { ganti) }\end{array}$ & $\begin{array}{l}\text { Orang yang berbicara atau menulis (dalam } \\
\text { ragam resmi atau biasa) }\end{array}$ \\
\hline شَكَوَائي & Keluh kesah & $\begin{array}{l}\text { Segala ucapan yang terlahir karena } \\
\text { kesusahan (kepedihan dan sebagainya) }\end{array}$ \\
\hline
\end{tabular}

Maka dapat disimpulkan lirik pada dua baris kedua memiliki makna denotatif yaitu aku tak memiliki siapapun selain Engkau (Tuhan). Tuhanku, yang mendengar keluh kesahku.

3. Makna denotasi pada dua larik ketiga pada lagu Kun Fayakun

$$
\text { إلا الذي قد دعيب الدعاء }
$$

\section{Lirik Terjemah Makna KBBI}

\begin{tabular}{ccl}
\hline من & Siapa & $\begin{array}{l}\text { Kata tanya untuk menanyakan nomina } \\
\text { insan }\end{array}$ \\
\hline يستجيب & Mengabulkan & $\begin{array}{l}\text { Meluluskan (permintaan, doa, harapan, } \\
\text { dan sebagainya); mengiakan }\end{array}$ \\
\hline Ded & Doa & $\begin{array}{l}\text { Permohonan (harapab, permintaan, pujian) } \\
\text { kepada Tuhan }\end{array}$
\end{tabular}


ALIBBAA'?: Jurnal Pendidikan Bahasa Arab, 3 (1), 2022

\begin{tabular}{|c|c|c|}
\hline$y !$ & Kecuali & $\begin{array}{l}\text { Tidak termasuk (dalam golongan, aturan, } \\
\text { dan sebagainya yang umum); yang selain } \\
\text { dari; yang lain; daripada }\end{array}$ \\
\hline 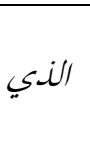 & Yang & $\begin{array}{l}\text { Kata untuk menyatakan bahwa kata atau } \\
\text { kalimat yang berikutnya diutamakan atau } \\
\text { dibedakan dari yang lain }\end{array}$ \\
\hline قل & Telah & $\begin{array}{l}\text { Sudah (untuk menyatakan perbuatan, } \\
\text { keadaan dan sebagainya yang sempurna, } \\
\text { lampau, atau selesai) }\end{array}$ \\
\hline دعا & Doa & $\begin{array}{l}\text { Permohonan (harapan, permintaan, pujian) } \\
\text { kepada Tuhan }\end{array}$ \\
\hline نا & Kami & $\begin{array}{l}\text { Yang berbicara bersama dengan orang lain } \\
\text { (tidak termasuk yang diajak berbicara); } \\
\text { yang menulis atas nama kelompok, tidak } \\
\text { termasuk pembaca }\end{array}$ \\
\hline 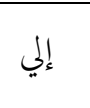 & Ke; kepada & $\begin{array}{l}\text { Kata depan untuk menandai arah atau } \\
\text { tujuan }\end{array}$ \\
\hline \& & Dia (kata ganti) & $\begin{array}{l}\text { Persona tunggal yang (dibicarakan, di luar } \\
\text { pembicara dan kawan bicara; ia) }\end{array}$ \\
\hline
\end{tabular}

Maka makna denotasi pada dua baris ketiga adalah siapa lagi yang mengabulkan doa, kecuali Allah yang menyerukan kita untuk berdoa.

4. Makna denotasi pada dua baris keempat pada lirik lagu Kun Fayakun

معن لي غيرك ربي

\begin{tabular}{ccc}
\hline Lirik & Terjemah & Makna KBBI \\
\hline$ن َ$ & Siapa & Kata tanya untuk menanyakan nomina insan \\
\hline$J$ & Bagi & $\begin{array}{l}\text { Kata depan untuk menyatakaan perihal; } \\
\text { akan (hal); tentang (hal); menurut }\end{array}$ \\
\hline
\end{tabular}




\begin{tabular}{|c|c|c|}
\hline & & (pendapat) \\
\hline ي & $\begin{array}{l}\text { Saya (kata } \\
\text { ganti) }\end{array}$ & $\begin{array}{l}\text { Orang yang berbicara atau menulis (dalam } \\
\text { ragam resmi atau biasa) }\end{array}$ \\
\hline 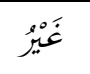 & Selain & Kecuali; lain daripada \\
\hline كَ & $\begin{array}{l}\text { Kamu (kata } \\
\text { ganti) }\end{array}$ & $\begin{array}{l}\text { Yang diajak bicara; yang disapa (dalam } \\
\text { ragam akrab atau kasar) }\end{array}$ \\
\hline 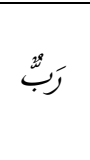 & tuhan & $\begin{array}{l}\text { Sesuatu yang diyakini, dipuja, dan } \\
\text { disembah oleh manusia sebagai yang } \\
\text { Mahakuasa, Mahaperkasa, dan sebagainya }\end{array}$ \\
\hline ي & $\begin{array}{l}\text { Saya (kata } \\
\text { ganti) }\end{array}$ & $\begin{array}{l}\text { Orang yang berbicara atau menulis (dalam } \\
\text { ragam resmi atau biasa) }\end{array}$ \\
\hline معتود & Terikat & $\begin{array}{l}\text { (telah) diikat (disusun, dirangkaikan, dan } \\
\text { sebagainya) }\end{array}$ \\
\hline في & Di dalam & Kata depan untuk menandai arah atau tujuan \\
\hline 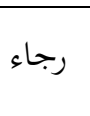 & Harapan & $\begin{array}{l}\text { Sesuatu yang (dapat) diharapkan; keinginan } \\
\text { supaya menjadi kenyataan }\end{array}$ \\
\hline ي & $\begin{array}{l}\text { Saya (kata } \\
\text { ganti) }\end{array}$ & $\begin{array}{l}\text { Orang yang berbicara atau menulis (dalam } \\
\text { ragam resmi atau biasa) }\end{array}$ \\
\hline
\end{tabular}

Maka dapat disimpulkan bahwa makna denotasi dari dua baris lirik keempat adalah aku tak memiliki siapa pun selain Engkau Tuhanku, kepadaNya terikat harapanku.

5. Makna denotasi pada dua baris kelima pada lirik lagu Kun Fayakun لا تعاملني بذبي

ياجواد ياكريم

\section{Lirik Terjemah Makna KBBI}

\begin{tabular}{ccl}
\hline y & $\begin{array}{c}\text { Jangan } \\
\text { hubungkan aku }\end{array}$ & $\begin{array}{l}\text { Hubungan: ikatan; pertalian (keluarga, } \\
\text { persahabatan, dan sebagainya) }\end{array}$ \\
\hline & Dengan & Beserta; bersama-sama
\end{tabular}


ALIBBAA': Jurnal Pendidikan Bahasa Arab, 3 (1), 2022

\begin{tabular}{ccl}
\hline ذنب & Dosa & $\begin{array}{l}\text { Perbuatan yang melanggar hukum Tuhan } \\
\text { atau agama }\end{array}$ \\
\hline$ي$ & $\begin{array}{c}\text { Saya (kata } \\
\text { ganti) }\end{array}$ & $\begin{array}{l}\text { Orang yang berbicara atau menulis (dalam } \\
\text { ragam resmi atau biasa) }\end{array}$ \\
\hline Maha Pemurah & $\begin{array}{l}\text { Orang yang suka memberi; orang yang } \\
\text { tidak pelit; orang yang murah hati }\end{array}$ \\
\hline ياجوريم & Maha Mulia & $\begin{array}{l}\text { Tinggi (tentang kedudukan, pangkat, } \\
\text { martabat), tertinggi, terhormat }\end{array}$ \\
\hline
\end{tabular}

Kesimpulannya makna denotasi pada dua baris kelima adalah jangan Kau hubungkan aku dengan dosaku, wahai yang Maha Pemurah wahai yang Maha Mulia.

6. Makna denotasi pada dua baris keenam pada lirik lagu Kun Fayakun

اني عبد ضعيف

حظه لا يستقيم

\begin{tabular}{|c|c|c|}
\hline Lirik & Terjemah & Makna KBBI \\
\hline انّ & Sesungguhnya & Sebenarnya; sebetulnya; bahwasanya \\
\hline ي & Aku (kata ganti) & $\begin{array}{l}\text { Orang yang berbicara atau menulis (dalam } \\
\text { ragam resmi atau biasa) }\end{array}$ \\
\hline عبد & Hamba & Saya (untuk merendahkan diri) \\
\hline ضعيف & Lemah & Tidak kuat, tidak bertenaga \\
\hline حظ & Nasib & $\begin{array}{l}\text { Sesuatu yang sudah ditentukan oleh Tuhan } \\
\text { atas diri seseorang; takdir }\end{array}$ \\
\hline هـ & Dia & $\begin{array}{l}\text { Persona tunggal yang dibicarakan, di luar } \\
\text { pembicara dan kawan bicara }\end{array}$ \\
\hline لا يستقيم & $\begin{array}{l}\text { Tidak selalu } \\
\text { lurus }\end{array}$ & Lurus berarti tepat benar; betul \\
\hline
\end{tabular}


Maka dapat disimpulkan bahwa makna denotasi pada dua baris keenam adalah sesungguhnya aku hamba yang lemah, nasibnya tidak lurus.

7. Makna denotasi pada dua baris ketujuh pada lirik lagu Kun Fayakun لا لا تحرمني ربي

من لطفك العميم

\section{$\begin{array}{lll}\text { Lirik Terjemah } & \text { Makna KBBI }\end{array}$}

\begin{tabular}{|c|c|c|}
\hline لا لا تحرم & $\begin{array}{c}\text { Jangan } \\
\text { haramkan aku }\end{array}$ & $\begin{array}{l}\text { Haram berarti terlarang (oleh agama } \\
\text { Islam); tidak halal }\end{array}$ \\
\hline ي & $\begin{array}{l}\text { Aku (kata } \\
\text { ganti) }\end{array}$ & $\begin{array}{l}\text { Orang yang berbicara atau menulis (dalam } \\
\text { ragam resmi atau biasa) }\end{array}$ \\
\hline رَبُُّ & Tuhan & $\begin{array}{l}\text { Sesuatu yang diyakini, dipuja, dan } \\
\text { disembah oleh manusia sebagai yang } \\
\text { Mahakuasa, Mahaperkasa, dan sebagainya }\end{array}$ \\
\hline ي & $\begin{array}{l}\text { Aku (kata } \\
\text { ganti) }\end{array}$ & $\begin{array}{l}\text { Orang yang berbicara atau menulis (dalam } \\
\text { ragam resmi atau biasa) }\end{array}$ \\
\hline من & Dari & $\begin{array}{l}\text { Kata depan yang menyatakan tempat } \\
\text { permulaan (dalam ruang, waktu, deretan, } \\
\text { dan sebagainya) }\end{array}$ \\
\hline لطف & Kelembutan & Kehalusan (budi pekerti dan sebagainya) \\
\hline 5 & $\begin{array}{l}\text { Kamu (kata } \\
\text { ganti) }\end{array}$ & $\begin{array}{l}\text { Yang diajak bicara; yang disapa (dalam } \\
\text { ragam akrab atau kasar) }\end{array}$ \\
\hline 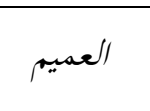 & Sempurna & $\begin{array}{l}\text { Utuh dan lengkap segalanya (tidak bercacat } \\
\text { dan bercela) }\end{array}$ \\
\hline
\end{tabular}

Maka, kesimpulannya makna denotasi dari dua baris ketujuh adalah jangan Kau haramkan aku Tuhanku, dari kelembutanMu yang sempurna. 
8. Makna denotasi pada dua baris kedelapan pada lirik lagu Kun Fayakun

\begin{tabular}{|c|c|c|}
\hline Lirik & Terjemah & Makna KBBI \\
\hline فستام & Sakit & $\begin{array}{l}\text { Tidak nyaman di tubuh atau bagian tubuh } \\
\text { karena menderita sesuatu (demam, sakit } \\
\text { perut dan sebagainya) }\end{array}$ \\
\hline ي & $\begin{array}{l}\text { Aku (kata } \\
\text { ganti) }\end{array}$ & $\begin{array}{l}\text { Orang yang berbicara atau menulis (dalam } \\
\text { ragam resmi atau biasa) }\end{array}$ \\
\hline اتعبت & Melelahkan & $\begin{array}{l}\text { Menyebabkan (membuat) lelah, } \\
\text { memenatkan }\end{array}$ \\
\hline ي & $\begin{array}{l}\text { Aku (kata } \\
\text { ganti) }\end{array}$ & $\begin{array}{l}\text { Orang yang berbicara atau menulis (dalam } \\
\text { ragam resmi atau biasa) }\end{array}$ \\
\hline L & Wahai & $\begin{array}{l}\text { Kata seru untuk menarik perhatian, } \\
\text { memanggil, memperingatkan, dan } \\
\text { sebagainya }\end{array}$ \\
\hline رَبُُّ & Tuhan & $\begin{array}{l}\text { Sesuatu yang diyakini, dipuja, dan } \\
\text { disembah oleh manusia sebagai yang } \\
\text { Mahakuasa, Mahaperkasa, dan sebagainya }\end{array}$ \\
\hline ي & $\begin{array}{l}\text { Aku (kata } \\
\text { ganti) }\end{array}$ & $\begin{array}{l}\text { Orang yang berbicara atau menulis (dalam } \\
\text { ragam resmi atau biasa) }\end{array}$ \\
\hline L & Wahai & $\begin{array}{l}\text { Kata seru untuk menarik perhatian, } \\
\text { memanggil, memperingatkan, dan } \\
\text { sebagainya }\end{array}$ \\
\hline الرحيم & Penyayang & $\begin{array}{l}\text { Orang yang penuh kasih sayang; pengasih } \\
\text { pecinta }\end{array}$ \\
\hline
\end{tabular}

Maka dapat disimpulkan makna denotasi pada dua baris kedelapan adalah sakitku melelahkanku, wahai Tuhanku yang Maha Penyayang. 
9. Makna denotasi pada baris selanjutnya pada lirik lagu Kun Fayakun قل له كن فيكون

\begin{tabular}{|c|c|c|}
\hline Lirik & Terjemah & Makna KBBI \\
\hline قل & Katakanlah & $\begin{array}{l}\text { Bentuk perintah dari menyebutkan; } \\
\text { menuturkan }\end{array}$ \\
\hline 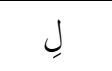 & Kepada & Kata depan untuk menandai tujuan orang \\
\hline هُ & Dia & $\begin{array}{l}\text { Persona tunggal yang dibicarakan, di luar } \\
\text { pembicara dan kawan bicara }\end{array}$ \\
\hline كن & Jadilah & Bentuk perinta dari menjadi \\
\hline فيكون & Terjadi & $\begin{array}{l}\text { Sudah dijadikan (diadakan); sudah berlaku } \\
\text { (tentang suatu peristiwa) }\end{array}$ \\
\hline
\end{tabular}

Kesimpulannya makna denotasi pada baris ini adalah katakanlah kepadanya "jadilah!" maka akan terjadi.

10. Makna denotasi pada dua baris kesepuluh pada lirik lagu Kun Fayakun

$$
\begin{aligned}
& \text { لا حول لي كي أحال إليه } \\
& \text { لإلعطاء }
\end{aligned}
$$

\begin{tabular}{|c|c|c|}
\hline Lirik & Terjemah & Makna KBBI \\
\hline L & Wahai & $\begin{array}{l}\text { Kata seru untuk menarik perhatian, } \\
\text { memanggil, memperingatkan, dan } \\
\text { sebagainya }\end{array}$ \\
\hline مجزلا & $\begin{array}{c}\text { Yang } \\
\text { berlimpah }\end{array}$ & $\begin{array}{l}\text { Sangat banyak; lebih dari cukup; berlimpah- } \\
\text { limpah }\end{array}$ \\
\hline ب & Dengan & Beserta; bersama-sama \\
\hline العطاء & Pemberian & Sesuatu yang diberikan \\
\hline لا حول & Tiada daya & $\begin{array}{l}\text { Daya berarti kemampuan melakukan } \\
\text { sesuatu atau kemampuan bertindak }\end{array}$ \\
\hline
\end{tabular}


ALIBBAA': Jurnal Pendidikan Bahasa Arab, 3 (1), 2022

\begin{tabular}{ccl}
\hline$ل$ & Bagi & $\begin{array}{l}\text { Kata depan untuk menyatakan perihal; akan } \\
\text { (hal); tentang (hal); menurut (pendapat) }\end{array}$ \\
\hline s & $\begin{array}{c}\text { Aku (kata } \\
\text { ganti) }\end{array}$ & $\begin{array}{l}\text { Orang yang berbicara atau menulis (dalam } \\
\text { ragam resmi atau biasa) }\end{array}$ \\
\hline Untuk & $\begin{array}{l}\text { Kata depan untuk menyatakan bagi...; } \\
\text { bagian }\end{array}$ \\
\hline إلى & Mengatasi & Menguasai (keadaan dan sebagainya) \\
\hline ke; kepada & Kata depan untuk menandai arah atau tujuan \\
\hline & Dia & $\begin{array}{l}\text { Persona tunggal yang dibicarakan, di luar } \\
\text { pembicara dan kawan bicara }\end{array}$ \\
\hline
\end{tabular}

Maka dapat disimpulkan bahwa makna denotasi dari dua baris di atas adalah wahai yang berlimpah pemberianNya, tiada kekuatan bagiku untuk mengatasinya.

11. Makna denotasi pada dua baris kesepuluh pada lirik lagu Kun Fayakun

$$
\text { من كل داء خلقت دواء لقبي شفاء }
$$

\begin{tabular}{cll}
\hline Lirik & Terjemah & \multicolumn{1}{c}{ Makna KBBI } \\
\hline$ي$ & Wahai & $\begin{array}{l}\text { Kata seru untuk menarik perhatian, } \\
\text { memanggil, memperingatkan, dan } \\
\text { sebagainya }\end{array}$ \\
\hline Siapa & Seseorang yang tidak tentu \\
\hline$J$ & Untuk & Kata depan yang menyatakan bagi \\
\hline & Hati & $\begin{array}{l}\text { Sesuatu yang ada di dalam tubuh manusia } \\
\text { yang dianggap sebagai tempat segala } \\
\text { perasaan batin dan tempat menyimpan } \\
\text { pengertian (perasaan dan sebagainya) }\end{array}$ \\
\hline
\end{tabular}




\begin{tabular}{|c|c|c|}
\hline 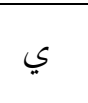 & $\begin{array}{l}\text { Saya (kata } \\
\text { ganti) }\end{array}$ & $\begin{array}{l}\text { Orang yang berbicara atau menulis (dalam } \\
\text { ragam resmi atau biasa) }\end{array}$ \\
\hline ل مغاء & Obat & $\begin{array}{l}\text { Bahan untuk mengurangi, menghilangkan } \\
\text { penyakit, atau menyembuhkan seseorang } \\
\text { dari penyakit }\end{array}$ \\
\hline من & Dari & $\begin{array}{l}\text { Kata depan yang menyatakan tempat } \\
\text { permulaan (dalam ruang, waktu, deretan, } \\
\text { dan sebagainya) }\end{array}$ \\
\hline كل & Setiap & Satu; saban \\
\hline داء & Penyakit & $\begin{array}{l}\text { Sesuatu yang menyebabkan trjadinya } \\
\text { gangguan pada makhluk hidup }\end{array}$ \\
\hline خلق & Menciptakan & $\begin{array}{l}\text { Menjadikan sesuatu yang baru tidak dengan } \\
\text { bahan }\end{array}$ \\
\hline ت & $\begin{array}{l}\text { Kamu (kata } \\
\text { ganti) }\end{array}$ & $\begin{array}{l}\text { Yang diaak bicara; yang disapa (dalam } \\
\text { ragam akrab atau kasar) }\end{array}$ \\
\hline دواء & Obat & $\begin{array}{l}\text { Bahan untuk mengurangi, menghilangkan } \\
\text { penyakit, atau menyembuhkan seseorang } \\
\text { dari penyakit }\end{array}$ \\
\hline
\end{tabular}

Maka dapat diambil kesimpulan bahwa makna denotasi dari dua baris tersebut di atas adalah wahai yang menjadi obat bagi hatiku, yang menciptakan obat di setiap penyakit.

12. Makna denotasi pada dua baris ke duabelas pada lirik lagu Kun Fayakun

$$
\text { يشفيني يا مو لاي غيرك ربي }
$$

\begin{tabular}{ccl}
\hline Lirik & Terjemah & \multicolumn{1}{c}{ Makna KBBI } \\
\hline$ن َ$ & Siapa & $\begin{array}{l}\text { Kata tanya untuk menanyakan nomina } \\
\text { insan }\end{array}$ \\
\hline$J$ & Bagi & $\begin{array}{l}\text { Kata depan untuk menyatakaan perihal; } \\
\text { akan (hal); tentang (hal); menurut }\end{array}$ \\
\hline
\end{tabular}




\begin{tabular}{|c|c|c|}
\hline & & (pendapat) \\
\hline 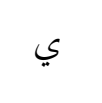 & Saya (kata ganti) & $\begin{array}{l}\text { Orang yang berbicara atau menulis (dalam } \\
\text { ragam resmi atau biasa) }\end{array}$ \\
\hline 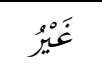 & Selain & Kecuali; lain daripada \\
\hline كَ & Kamu & $\begin{array}{l}\text { Yang diaak bicara; yang disapa (dalam } \\
\text { ragam akrab atau kasar) }\end{array}$ \\
\hline 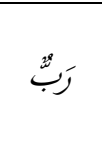 & Tuhan & $\begin{array}{l}\text { Sesuatu yang diyakini, dipuja, dan } \\
\text { disembah oleh manusia sebagai yang } \\
\text { Mahakuasa, Mahaperkasa, dan sebagainya }\end{array}$ \\
\hline 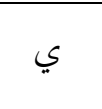 & Saya (kata ganti) & $\begin{array}{l}\text { Orang yang berbicara atau menulis (dalam } \\
\text { ragam resmi atau biasa) }\end{array}$ \\
\hline يشنيني & $\begin{array}{l}\text { Menyembuhkan } \\
\text { aku }\end{array}$ & $\begin{array}{l}\text { Menjadi sehat kembali (tentang orang } \\
\text { sakit, dari sakit atau penyakit); pulih }\end{array}$ \\
\hline ي & Wahai & $\begin{array}{l}\text { Kata seru untuk menarik perhatian, } \\
\text { memanggil, memperingatkan, dan } \\
\text { sebagainya }\end{array}$ \\
\hline مولاي & $\begin{array}{l}\text { Yang Maha } \\
\text { sempurna }\end{array}$ & $\begin{array}{l}\text { Utuh dan lengkap segalanya (tidak } \\
\text { bercacat dan bercela). }\end{array}$ \\
\hline
\end{tabular}

Kesimpulannya, makna denotasi dari dua baris keduabelas ini adalah aku tak memiliki siapapun selain Engkau Tuhanku, yang menyembuhkanku wahai yang Maha sempurna.

Makna denotasi dapat diartikan bahwa tingkat pertandaan yang menjelaskan hubungan antara signifier dan signified, atau antara tanda dan rujukannya pada realitas, yang menghasilkan makna yang eksplisit, langsung, dan pasti. ${ }^{21}$ Makna denotasi juga merupakan makna paling nyata dari tanda, apa yang digambarkan tanda terhadap sebuah objek. ${ }^{22}$ Teori tersebut dapat mengungkapkan

${ }^{21}$ Prina Yelly, "Analisis Makhluk Superior (Naga) Dalam Legenda Danau Kembar.," Journal Serunai Bahasa Indonesia, Vol. 16 No. 2, 2019: 123. https://ejournal.stkipbudidaya.ac.id/index.php/je/article/view/200

${ }^{22}$ Faizal Surya Afdhaludin, "Pesan Dakwah Habiburrahman El Shirazy Dalam Novel Bidadari Bermata Bening Karya (Analisis Semiotik Model Roland Barthes)," Skripsi (2018): 15. http://digilib.uinsby.ac.id/28633/ 
bahwa lirik lagu Kun Fayakun memiliki makna denotasi atau makna asli dari setiap kata pada lirik lagu tersebut.

\section{Analisis Makna Konotasi pada Lirik Lagu Kun Fayakun}

Berdasarkan makna denotasi yang sudah dijabarkan sebelumnya, maka selanjutnya makna pada tataran kedua, yaitu konotasi. Merujuk pada bagan yang disajikan sebelumnya, bahwa tanda atau makna denotasi juga merupakan penanda konotatif. Kemudian penanda konotatif tersebut akan memunculkan petanda konotatif yang menjadi dasar munculnya tanda konotatif. ${ }^{23}$

1. Makna konotasi pada dua larik pertama lagu Kun Fayakun

Ketika musibah menimpa

Aku datang merendah memohon kepada-Nya

Makna konotasi pada lirik tersebut yaitu setiap manusia pasti menghadapi cobaan, menurut Abd al-Qadir Abu Faris (dikutip dari Lilik Ummi Kaltsum, 2018) jika manusia telah menyadari makna hakiki dari ujian atau cobaan, maka seharusnya dia tetap mempertahankan aqidah dan selalu berada pada jalan-Nya meskipun harus menderita dan mengalami berbagai kesulitan. Hal itu akan dan pasti terjadi pada semua manusia karena memang jalan cobaan tidak dapat dihindari oleh siapapun, mukmin atau kafir. ${ }^{24}$

Selanjutnya dalam menghadapi cobaan tersebut manusia akan merendah. Maksud merendah di sini bukan merendahkan badan atau membungkuk, melainkan memperbanyak sujud dan memohon kapada Tuhan. Dengan adanya sikap merendah, maka Allah akan memberikan apa yang kita minta. Artinya tiada kemudahan kecuali atas kuasa Tuhan.

2. Makna konotasi pada dua larik kedua lagu Kun Fayakun

Aku tak memiliki siapapun selain Engkau

Engkau Tuhanku yang mendengar keluh kesahku

Makna konotasi pada lirik tersebut yaitu seorang hamba yang merasa tidak memiliki siapa pun. Maksud di sini bukan berarti orang tersebut hidup sendiri, tidak memiliki orang tua, tidak

${ }^{23}$ Aritonang and Doho, "Analisis Semiotika Roland Barthes Terhadap Lirik Lagu Band Noah 'Puisi Adinda ."”

${ }^{24}$ Lilik Ummi Kaltsum, "Cobaan Hidup Dalam Al- Qur' An ( Studi Ayat Ayat Fitnah Dengan Aplikasi Metode Tafsir Tematik )" Ilmu Ushuluddin, Vol. 5 No. 2, 2018: 107-138. http://journal.uinjkt.ac.id/index.php/ilmuushuluddin/article/view/12778 
memiliki teman. Melainkan karena adanya keyakinan penuh bahwa Engkau (Tuhan) adalah dzat yang selau ada ketika seorang hamba sedang dalam keadaan membutuhkan bantuan. Seperti dalam firmannya QS. At-Taubah: 40

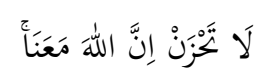

"Jangan engkau bersedih, sesungguhnya Allah bersama kita."

3. Makna konotasi pada dua larik ketiga lagu Kun Fayakun

Siapa lagi yang mengabulkan doa

Kecuali Allah yang menyerukan kita untuk berdoa

Makna konotasi pada lirik tersebut yaitu doa menjadi alat pengantar terbaik yang mampu menghubungkan antara pencipta dan makhluk. Allah tidak akan menyuruh hamba-Nya melakukan sesuatu tanpa Dia memberikan jalan kemudahannya. Begitu juga dengan seruan untuk senantiasa berdoa, karena Allah akan mengabulkannya. Seperti dalam firman Allah QS. Al-Mu'min ayat 60

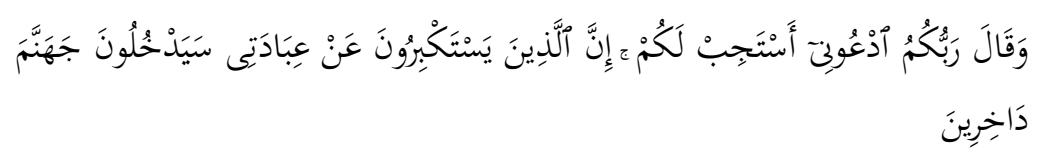

"Dan Tuhanmu berfirman: "Berdoalah kepada-Ku, niscaya akan Kuperkenankan bagimu. Sesungguhnya orang-orang yang menyombongkan diri dari menyembah-Ku akan masuk neraka Jahannam dalam keadaan hina dina."

4. Makna konotasi pada dua larik keempat lagu Kun Fayakun Aku tak memiliki siapa pun selain Engkau

Tuhanku kepada-Nya terikat harapanku

Makna konotasi pada lirik tersebu yaitu bahwasanya kita sering dikecewakan oleh kenyataan yang tidak sesuai dengan harapan. Tetapi hal tersebuat mengajarkan bahwa satu-satunya tempat berharap hanyalah kepada Allah. Sebab Allah tidak pernah sekalipun menolak permohonan hamba-Nya. Seperti dalam QS. AlInsyirah ayat 8

$$
\text { وَإِلَى رَبِّكَ فَارْغَبْ }
$$

"Dan hanya kepada Tuhanmulah (Allah SWT) hendaknya kamu berharap"

5. Makna Konotasi pada dua larik kelima dalam lagu Kun Fayakun Jangan Kau hubungkan aku dengan dosaku Wahai yang Maha Pemurah lagi yang Maha Mulia 
Makna konotasi pada lirik tersebut yaitu kerendahan hati seorang hamba yang mengakui dosa-dosanya. Walaupun manusia dilahirkan dalam keadaan suci dan mulia, namun tidak dapat dipungkuri bahwa manusia tidak bisa luput dari dosa. Di lain sisi, Allah sendiri menyatakan bahwa hamba-hambanya yang sudah melampaui batas dalam dosa masih bisa diampuni. Hal ini ditegaskan dalam QS. Az-Zumar ayat 53

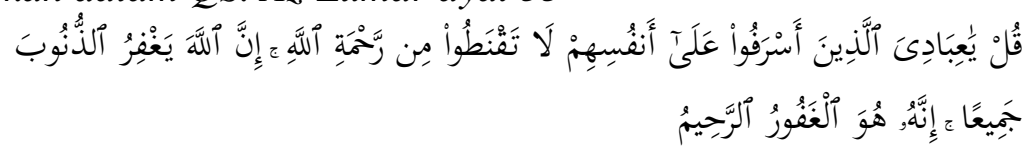

"Katakanlah: "Hai hamba-hamba-Ku yang malampaui batas terhadap diri mereka sendiri, janganlah kamu berputus asa dari rahmat Allah. Sesungguhnya Allah mengampuni dosa-dosa semuanya. Sesungguhnya Dialah Yang Maha Pengampun lagi Maha Penyayang."

6. Makna konotasi pada dua larik keenam dalam lagu Kun Fayakun Sesungguhnya aku hamba yang lemah Yang nasibnya selalu tidak lurus

Makna konotasi pada lirik tersebut yaitu kerendahan hati seorang hamba yang merasa hidupnya tidak bisa selalu sesuai harapan, adakalanya berada di bawah dan adakalanya di atas. Hal ini setara dengan Kuasa untuk menentukan apa saja yang dikehendaki-Nya. Oleh sebab itu setiap muslim harus yakin dan percaya bahwa Allah Maha Kuasa dan Maha mengetahui tentang nasib seluruh makhluk. Allah sudah menentukan nasib setiap makhluknya, tetapi tidak seorang pun makhluk yang mengetahui nasibnya. ${ }^{25}$

7. Makna konotasi pada dua larik ketujuh dalam lagu Kun Fayakun Jangan Kau haramkan aku Tuhanku Dari kelembutanmu yang sempurna

Makna konotasi pada lirik yaitu kerendahan hati seorang hamba yang memohon agar tidak dijauhkan dari kelembutan Tuhannya. Maksud kelembutan di sini adalah cara Allah mengatur makhluknya dalam penciptaan dengan penuh kelemah-lembutan dan kasih sayang. Maksud lirik ini juga berkaitan dengan lirik

${ }^{25}$ Emil Septia, Silvia Marni, and Armet Armet, "Representasi Nilai Religi Dan Kepengarangan Puisi-Puisi Karya Taufik Ismail," Poetika: Jurnal Ilmu Sastra, Vol. 7 No. 1, 2019: 32-50. https://jurnal.ugm.ac.id/poetika/article/view/43493 
sebelumnya, di mana seorang hamba yang hakikatnya lemah membutuhkan kelembutan dari Tuhannya.

8. Makna konotasi pada dua larik kedepalan dalam lagu Kun Fayakun Sakitku melemahkanku Wahai Tuhan yang Maha Penyayang

Makna konotasi pada lirik tersebut yaitu manusia diciptakan dengan sifat suka berkeluh kesah, hal ini dijelaskan dalam QS. AlMa' arij ayat 19-21

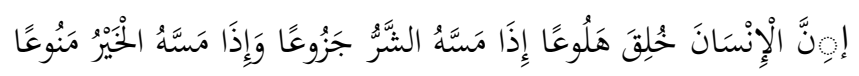

"Sesungguhnya manusia diciptakan bersifat keluh kesah lagi kikir. Apabila ia ditimpa kesusahan ia berkeluh kesah, dan apabila ia mendapat kebaikan (harta) ia amat kikir."

9. Makna konotasi pada larik kesembilan dalam lagu Kun Fayakun Katankanlah kepadanya, jadilah maka akan terjadi

Makna konotasi pada lirik tersebut yaitu kalimat ini menunjukkan dahsyatnya kuasa Allah swt. Di mana segala yang dikehendaki-Nya pasti terjadi tanpa memerlukan bantuan dari pihak lain. Seperti dijelaskan dalam QS Al-Baqarah ayat 117

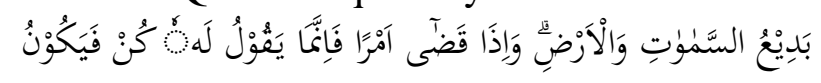

(Allah) pencipta langit dan bumi. Apabila Dia hendak menetapkan sesuatu, Dia hanya berkata kepadanya, "Jadilah!” Maka jadilah sesuatu itu.

10. Makna konotasi pada dua larik kesepuluh dalam lagu Kun Fayakun Wahai yang berlimpah pemberian-Nya

Tiada kekuatan bagiku untuk mengatasinya

Makna konotasi pada lirik tersebut yaitu sikap seorang hamba yang merasa kesusahan dalam menghadapi masalah-masalah dan dia bertawakal menyerahkannya kepada Allah yang berlimpah karunia. Seperti yang dijelaskan dalam QS. Yunus ayat 84

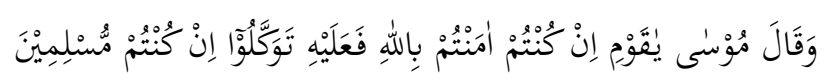

Dan Musa berkata, “Wahai kaumku! Apabila kamu beriman kepada Allah,

maka bertawakallah kepada-Nya, jika kamu benar-benar orang Muslim (berserah diri).'

11. Makna konotasi pada dua larik kesebelas dalam lagu Kun Fayakun Wahai yang menjadi obat bagi hatiku 


\section{Yang menciptakan obat disetiap penyakit}

Makna konotasi pada lirik tersebut yaitu bahwasanya Allah memiliki nama yaitu Asy-Syafi yang artinya Allah Maha menyembuhkan. Dikaitkan juga dalam QS. Asy-Syu'ara' ayat 80

$$
\text { وَإِذَا مَرِضْتُ فَهُوَ يَشْْْفِنِ }
$$

"dan apabila aku sakit, Dialah yang menyembuhkan aku”

12. Makna konotasi pada dua larik ke duabelas dalam lagu Kun

Fayakun

Aku tak memiliki siapa pun selain Engkau Tuhanku

Yang menyembuhkanku wahai yang Maha Sempurna

Makna konotasi pada lirik tersebut yaitu berkaitan dengan makna pada larik-larik sebelumnya. Di mana seorang hamba yang merendah dan memuji Tuhannya ketika sedang dalam keadaan susah atau menghadapi cobaan seperti sakit dan musibah untuk mendapatkan bantuan dari-Nya.

Selanjutnya makna konotasi dapat diartikan sebuah kata yang dipengaruhi dan ditentukan oleh lingkungan tekstual dan lingkungan budaya. ${ }^{26}$ Sistem pemaknaan konotasi bersifat subjektif. Melibatkan emosional, perasaan pembaca serta simbol-simbol. Dalam konsep Barthes konotasi digunakan untuk menyikapi makna-makna yang tersembunyi. ${ }^{27} \mathrm{Hal}$ ini relevan dengan makna konotasi yang ada dalam lirik lagu Kun Fayakun, di mana makna dari kata yang tersusun sesuai dengan apa yang dalam teks tingkat kedua dan juga dipengaruhi oleh fakta kehidupan sehari-hari

\section{Kesimpulan}

Berdasarkan penelitian yang telah dilakukan, lirik lagu kun fayakun yang diciptakan oleh Muhammad bin Duhai dengan analisis semiotika Roland Barthes mempunyai 12 makna denotatif dan 12 konotatif. Penulis menyadari bahwa setiap hasil analisis per dua bait lirik lagu tersebut mempunyai makna keyakinan kepada Tuhan karena

\footnotetext{
${ }^{26}$ Putri Sion Sinaga, "Semiotika Umpama Bahasa Batak Toba: Pendekatan Roland Barthes," Jurnal Ilmiah Korpus, Vol. 5 No. 1, 2021: 81-92. https://ejournal.unib.ac.id/index.php/korpus/article/view/12600

${ }^{27}$ Haristin Vindi Astuti, "Citra Perempuan Berhijab Dalam Film Bulan Terbelah Di Langit Amerika,” Skripsi (2021): 33. http://etheses.iainponorogo.ac.id/13746/
} 
bentuk setiap ungkapan yang ada pada lirik merupakan petanda dan penanda. Makna keseluruhan dari lagu kun fayakun memperlihatkan keyakinan seorang hamba bahwa musibah yang menimba adalah bentuk dari kuasa Allah dan kerendahan seorang hamba untuk memohon perlindungan dan kelembutan dari Allah untuk menghadapi segala musibah yang menimpa.

Lagu kun fayakun yang dinyanyikan di tengah-tengah kehidupan manusia yang penuh dengan lika-liku perjuangan bukanlah suatu hal yang aneh, melainkan menjadi pengingat dan nasihat bagi para penikmat lagu tersebut. Berdasarkan penyataan tersebut, dapat disimpulkan bahwa lirik kun fayakun memiliki makna yang sesuai dengan apa yang terjadi di kehidupan manusia.

Penulis menyadari bahwa pemaknaan melalui tanda-tanda sangat penting, karena dapat membantu pendengar untuk memahami makna yang terkandung dalam suatu lirik lagu. Selain itu, bait per bait dari lirik lagu kun fayakun juga mengungkapkan bentuk pembelajaran bagi manusia atas segala hal yang terjadi di dunia ini, karena setiap yang ditakdirkan oleh Allah mengandung maksud untuk menjadikan manusia lebih bersyukur dan tetap berkeyakinan kepada Sang Pencipta. 


\section{Daftar Pustaka}

Astuti, Haristin Vindi. "Citra Perempuan Berhijab Dalam Film Bulan Terbelah Di Langit Amerika." Skripsi (2021).

Afdhaludin, Faizal Surya. "Pesan Dakwah Habiburrahman El Shirazy Dalam Novel Bidadari Bermata Bening Karya (Analisis Semiotik Model Roland Barthes)." Skripsi (2018).

Bahasa, Badan Pengembangan dan Pembinaan. "Kamus Besar Bahasa Indonesia Daring." https://kbbi.kemdikbud.go.id/

David Ardhy Aritonang and Yohannes Don Bosco Doho, "Analisis Semiotika Roland Barthes Terhadap Lirik Lagu Band Noah 'Puisi Adinda'," Ilmu Komunikasi dan Bisnis, Vol. 4, No. 2, 2019: 77103. http://www.journal.starki.id/index.php/JIK/article/view/217

Devi Arie Shandy, "Representasi Makna Pesan Dakwah Dalam Lirik Lagu Tomat (Tobat Maksiat) Pada Album Ingat Shalawat Karya Wali Band," Jurnal Online Mahasiswa (JOM) Bidang Ilmu Sosial dan Ilmu Politik, Vol. 1 No. 2, 2014: 1-15. https://jom.unri.ac.id/index.php/JOMFSIP/article/view/3010

Emil Septia, Silvia Marni, and Armet Armet, "Representasi Nilai Religi Dan Kepengarangan Puisi-Puisi Karya Taufik Ismail," Poetika: Jurnal Ilmu Sastra, Vol. 7, No. 1, 2019: 32-50. https://jurnal.ugm.ac.id/poetika/article/view/43493

Fitri, "Analisa Semiotik Makna Motivasi Lirik Lagu 'Cerita Tentang Gunung Dan Laut' Karya Payung Teduh." Jurnal Komunikasi, Vol. 8, $\quad$ No. 2017. https://ejournal.bsi.ac.id/ejurnal/index.php/jkom/article/view/3071

John, Asril, and Agung Eko Budi Waspada, "Analisis Semiotika Logo Rumah Makan Patinku," Proporsi, Vol. 3, No. 1, 2017: 33-43. http://e-journal.potensi-

utama.ac.id/ojs/index.php/PROPORSI/article/view/551

Lilik Ummi Kaltsum, “Cobaan Hidup Dalam Al- Qur'an (Studi Ayat Ayat Fitnah Dengan Aplikasi Metode Tafsir Tematik)" Ilmu Ushuluddin, Vol. 5, No. 2, 2018: 107-138. http://journal.uinjkt.ac.id/index.php/ilmuushuluddin/article/view/12778 
M Imron, "Semiotika Dalam Lirik Lagu Arab Kun Anta Yang Dipopulerkan Oleh Humood Alkhuder," Skripsi (2018). https://repository.uinjkt.ac.id/dspace/handle/123456789/40585.

Muhammad bin Duhai, penyair, Wawancara, Instagram, 7 September 2021.

Niswati Khoiriyah dan Syahrul Syah Sinaga, "Pemanfaatan Pemutaran Musik Terhadap Psikologis Pasien Pada Klinik Ellena Skin Care Di Kota Surakarta," Jurnal Seni Musik, Vol. 6, No. 2, 2017: 8190.

https://journal.unnes.ac.id/sju/index.php/jsm/article/view/20313.

Nova Dwiyanti, "Analisis Semiotik Citra Wanita Muslimah Dalam Film 'Assalamualaikum Beijing'." Tesis (2016): 1-111. http://repository.uinsu.ac.id/1351/

Prina Yelly, "Analisis Makhluk Superior (Naga) Dalam Legenda Danau Kembar.," Journal Serunai Bahasa Indonesia, Vol. 16, No. 2, 2019:

123. https://ejournal.stkipbudidaya.ac.id/index.php/je/article/view/200

Putri Sion Sinaga, "Semiotika Umpama Bahasa Batak Toba: Pendekatan Roland Barthes," Jurnal Ilmiah Korpus, Vol. 5 No. 1, 2021:

81-92. https://ejournal.unib.ac.id/index.php/korpus/article/view/12600

Rendi Patria, Abdurahman Abdurahman, Bakhtaruddin Nasution, "Interpretasi Makna Lirik Lagu-Lagu Grup Musik ERK dalam Album ERK: Kajian Semiotika", Jurnal Bahasa dan Sastra, Vol. 1, No. 2, 2013: 69-82. http://ejournal.unp.ac.id/index.php/ibs/article/view/1481

Rif'ati Fauzan, "Kandungan Lirik Lagu Insya Allah Karya Maher Zain dalam Perspektif Al-Qu'an" Skripsi (2016). http://repository.iiq.ac.id/handle/123456789/672

Rina Septiana, "MAKNA DENOTASI, KONOTASI DAN MITOS DALAM FILM KEIN WHO AM I KEIN SYSTEM IST SICHER (SUATU ANALISIS SEMIOTIK)," JURNAL ELEKTRONIK FAKULTAS SASTRA UNIVERSITAS SAM RATULANGI, Vol. $1, \quad$ No. $2, \quad 2019$ : $1-4$. https://ejournal.unsrat.ac.id/index.php/jefs/article/view/24151 
ALIBBAA': Jurnal Pendidikan Bahasa Arab, 3 (1), 2022

Saiful Qadar Basri, "Tari Remo (Ngremong): Sebuah Analisis Teori Semiotika Roland Barthes Tentang Makna Denotasi Dan Konotasi Dalam Tari Remo (Ngremong)," Jurnal Seni Tari Drama, Vol. 2, No. 1 2019: 55-69. https://journal.unesa.ac.id/index.php/geter/article/view/4800

https://www.youtube.com/watch?v=VQSUCfRoZPM 